\title{
Democratic governance (Studi mengenai governability dalam pengembangan UMKM berbasis e-commerce di KotaYogyakarta)
}

\author{
Nugroho, Hanantyo Sri* \\ Program Studi llmu Pemerintahan \\ Fakultas Ekonomi dan Sosial, Universitas AMIKOM Yogyakarta, Indonesia \\ Diterima Februari 2018; Disetujui April 2018; Dipublikasikan Juni 2018
}

\begin{abstract}
Abstrak
Tulisan ini memberikan gambaran tentang kualitas democratic governance terkait dengan kemampuan pemerintah kota Yogyakarta dalam melakukan pemberdayaan UMKM berbasis e-commerce. Dominasi gagasan tentang efektivitas, efisiensi, dan standarisasi tersebut merupakan gagasan yang dibawa oleh model pasar kedalam skema tata kelola pemerintahan di era e-governance. Tulisan ini memfokuskan pada peran pemerintah dalam melakukan program pemberdayaan UMKM berbasis e-commerce, serta peran pemerintah dalam menggunakan ruang dialog tersebut. Hasil tulisan adalah kemampuan pemerintah dalam melakukan pengembangan UMKM dengan berbasis e-commerce linier terhadap kualitas democratic governance, yakni pemberdayaan dan partisipasi. Selain itu, dalam penggunaan ruang dialog terdapat perasaan ewuhpekewuh. Perasaan ini memiliki kelebihan dalam meredam konflik dan menjaga konsensus yang telah disepakati. Namun, disisi lain perasaan ini kemudian tidak melahirkan sikap partisipatif dalam memanfaatkan ruang publik untuk memperbaiki pengembangan UMKM. Dengan demikian, pemanfaatan ruang publik lebih digunakan oleh pemerintah untuk melaksanakan implementasi kebijakan maupun program.
\end{abstract}

Kata Kunci : Democratic governance, Kapasitas Pemerintah, Pemberdayaan UMKM berbasis e-commerce.

\begin{abstract}
This paper provides an overview of the quality of democratic governance related to the ability of the Yogyakarta city government to empower the SMEs based on e-commerce. The dominance of the idea of effectiveness, efficiency, and standardization is the idea brought by the market model into the governance scheme of the era of e-governance. This paper focuses on the role of government in conducting the ecommerce based SMEs empowerment program, and the role of government in using the dialogue space. The result of writing is the ability of the government in developing SMEs with linear e-commerce based on the quality of democratic governance, namely empowerment and participation. In addition, in the use of dialogue space there is a feeling of ewuh-pekewuh. This feeling has advantages in reducing conflict and maintaining agreed consensus. However, on the other hand this feeling did not give birth to participatory attitude in exploiting public space to improve the development of SMEs. Thus, the use of public space is more used by the government to implement the implementation of policies and programs.
\end{abstract}

Keywords: Democratic governance, Government Capacity, empowerment of SMEs based on e-commerce

How to Cite : Sri , H,. N, (2018). Democratic governance (Studi mengenai governability dalam pengembangan UMKM berbasis e-commerce di KotaYogyakarta) 6 (1): 30-46

\begin{tabular}{ll}
\hline${ }^{*}$ Corresponding author: & P-ISSN-2549-9165 \\
E-mail: hanantyosrinugroho@gmail.com & e-ISSN -2580-2011
\end{tabular}


PENDAHULUAN

\section{Dinamika democratic governance pemberdayaan UMKM berbasis e-commerce}

Tulisan ini memberikan gambaran tentang kualitas democratic governance terkait dengan kemampuan pemerintah kota Yogyakarta dalam melakukan pemberdayaan UMKM berbasis e-commerce. Hal ini dikarenakan terpinggirnya nilai demokrasi, yakni pemberdayaan dan partisipasi dalam arus dominasi gagasan tentang efektivitas, efisiensi, dan standarisasi. Dominasi gagasan tentang efektivitas, efisiensi, dan standarisasi tersebut merupakan gagasan yang dibawa oleh model pasar kedalam skema tata kelola pemerintahan di era e-governance. Pada perkembangannya, berbagai kebijakan sosial telah dikembangkan oleh pemerintah dalam rangka memunculkan kapabilitas setiap individu terhadap pasar. Salah satu dari kebijakan tersebut adalah program pengembangan UMKM melalui e-commerce. Hal tersebut bertujuan agar UMKM yang telah ada di Yogyakarta dapat mengakses pasar yang lebih luas. Hal ini selaras dengan perkembangan teknologi informasi dan komunikasi serta pergeseran paradigma tata kelola pemerintahan, dimana paradigma yang sedang didorong adalah e-governance.

Pemerintah beranggapan bahwa UMKM adalah identitas dan kearifan lokal serta bentuk kemandirian yang dapat menjadi ujung tombak pemerintah dalam memenangkan pasar. Berdasarkan pada data Kemeninfo bahwa pengguna transaksi online mencapai 84,2 juta orang (Diandra, 2016).

Hal ini yang membuat pemerintah terus mendorong UMKM di bisnis e-commerce, salah satunya dengan program 8 juta UMKM go online (Viska, 2017). Selain itu, terdapat paket kebijakan XIV tentang peta jalan ecommerce, dimana terkait pendanaan, hibah untuk inkubator bisnis pendamping startup, dan dana USO untuk UMKM digital dan startup e-commerce platform (Humas Kemenko Perekonomian, 2016). Hal tersebut diharapkan dapat memacu pertumbuhan ekonomi yang bersifat inklusif dan berkelanjutan dalam memanfaatkan pasar maupun supply chain. Meskipun demikian, belum banyak UMKM yang memaksimalkan e-commerce untuk mendongkrak penjualan. Hal tersebut ditunjukkan pada data Nurbaya Initiative bahwa dari 50 juta pelaku UMKM yang ada di beberapa kota di Indonesia, baru sekitar 5 persen yang masuk kedalam jaringan online (Praditya, 2016). Lebih lanjut, para kalangan UMKM masih mengalami kendala teknis terkait dengan keberlanjutan dalam mempebarui produk maupun terkait dengan pemasaran produk. Terdapatnya keterbatasan UMKM dalam mengkases dan keberlanjutan mengakses program pemberdayaan UMKM berbasis e-commerce adalah ketidakmampuan pemerintah. Ketidakmampuan tersebut yang sebenarnya masih pada tataran pertarungan dari gagasan tentang efektivitas, efisiensi, dan standarisasi sehingga kualitas demokrasi terpinggirkan. Hal inilah yang kemudian coba dilihat pada tulisan ini, yakni apakah hal ini juga berlaku kedalam program 
pemberdayaan UMKM berbasis e-commerce di kota Yogyakarta.

Tercecernya telaah ini adalah pertanda ketidaksiapan kita dalam melakukan program pemberdayaan UMKM berbasis e-commerce. Kasus ini menarik setidaknya pada tiga hal. Pertama, adanya pola pikir yang telah terbentuk dari transformasi pemberdayaan masyarakat yang diakibatkan oleh pergeseran dalam tata kelola pemerintahan, yakni e-governance. Kedua, mengenai partisipasi terkait upaya warga untuk mengakses program pemberdayaan UMKM berbasis e-commerce dan juga penilaian terhadap keberhasilan dengan indikator dari terjadinya keuntungan yang dihasilkan, dimana hal tersebut dianggap mencerminkan efektivitas, efisiensi, dan standarisasi. Ketiga, governability terkait keberlanjutan peran pemerintah dalam melakukan program pemberdayaan masyarakat tersebut tidak melihat kepada dinamika yang terdapat dalam democratic governance, gagasan ini mendorong pemerintahan demokratis yang inklusif dengan menggunakan ruang dialog yang tidak memihak agar mencapai konsensus dan pembangunan, dimana pilihan kebijakan yang digunakan mencakup pemberdayaan dan partisipasi dalam kolaborasi bersama tersebut. Oleh karena itu, untuk memenuhi pengetahuan tentang democratic governance dibalik skema pemberdayaan UMKM berbasis e-commerce maka penulis memfokuskan pada peran pemerintah dalam melakukan program pemberdayaan masyarakat berupa pemberdayaan UMKM berbasis e-commerce, serta peran pemerintah terkait dengan menggunakan ruang dialog dalam program tersebut. Berangkat dari wacana tersebut, maka konsekuensi yang muncul adalah bagaimana peran Pemerintah Kota Yogyakarta dalam pengembangan UMKM berbasis e-commerce dan juga dinamika demokrasi dari penggunaan ruang dialog dalam pengembangan UMKM berbasis e-commerce tersebut.

Dalam beberapa literatur, terdapat tulisan terhadap peran pemerintah terhadap pemberdayaan UMKM. Pertama, agar mampu memainkan peran dalam jangka menengah di atas, pemerintah harus berani mengubah paradigma pemberdayaan yang selama ini dipakai, dimana mengubah asumsi klise selama ini yang memandang koperasi dan UMKM sebagai lembaga usaha yang skalanya remeh, lemah, terbelakang dan pantas dikasihani, sehingga programprogram pemberdayaan hendaknya jangan seperti program charity, yang menganggap bahwa anggaran yang dikeluarkan sematamata merupakan alokasi dana sosial tanpa upaya untuk meningkatkan kemandirian dan kedewasaan berpikir para pelaku usaha tersebut (Kumorotomo, 2008). Kedua, implementasi kebijakan pemerintah dalam pembinaan usaha kecil dan menengah untuk mengadapi ACFTA di kawasan PIK Pulogadung kurang berjalan baik dikarenakan variabel komunikasi, sumberdaya, dan kepatuhan (Dulman, 2011). 
Ketiga, proses pemberdayaan yang telah dilakukan oleh pemerintah hanya sebatas pemberian modal usaha sehingga kurang maksimalnya bantuan pemerintah dalam pengembangan Usaha Mikro Kecil dan Menengah (UMKM) (Kurniawan, 2014). Keempat, beberapa faktor yang menyebabkan proses eksekusi strategi untuk tugas pemberdayaan tidak sesuai yakni kebutuhan stakeholder eksternal terutama terkait penyediaan informasi mengenai kegiatan pemberdayaan UMKM yang tidak terakomodir, sosialisasi program kerja masih dilakukan secara parsial, dan program kerja yang terintegrasi dengan kementerian/lembaga lain yang memiliki fungsi untuk pemberdayaan UMKM belum optimal (Pasaribu, 2015). Beberapa tulisan tersebut menunjukkan lemahnya kapasitas pemerintah dalam melakukan program pemberdayaan. Lebih lanjut, terdapat beberapa tulisan terkait dengan keberhasilan dalam melakukan pemberdayaan masyarakat. Kelima, perencanaan maupun pencapaian hasil usahanya selalu diawasi serta dibina sehingga sasaran terhadap pembiayaan kredit yang dikucurkan bagi pelaku usaha mikro benar-benar tepat dalam pengembangan usahanya dan menjadi tumbuh serta mandiri (Siswanto, 2011). Keenam, keberhasilan kepala desa periode saat ini sangat dipengaruhi oleh partisipasi aktif masyarakat, dimana pemerintah desa melalui kepala desanya hanya menyediakan dan memfasilitasi ruang partisipasi sehingga munculnya semangat kebersamaan dan kepedulian pada pembangunan wilayah bagi masyarakat desa (Umar, 2013). Artinya, unsur pendampingan dan penciptaan ruang partisipasi dapat menjadi faktor keberhasilan dalam pemberdayaan masyarakat.

Dalam beberapa kajian teoritik, pelaksanaan democratic governance mendorong institusi menciptakan kondisi bagi partisipasi masyarakat, untuk mendatangkan benefit bagi pembangunan masyarakat dan menciptakan daya saing bagi pengembangan ekonomi daerah (Swasanany, 2013). Lebih lanjut, institusi kuat dan baiknya praktek tata kelola pemerintahan telah ditawarkan sebagai faktor penentu utama bagi pertumbuhan ekonomi yang tinggi (Abiwu, 2017). Di era digital sekarang ini, sistem pemerintahan yang hanya mengandalkan basis pengelolaan admnistrasi secara prosedural semata dan tidak berbasis reformasi strukturisasi birokrasi secara substansial untuk dapat mengangkat kualitas administasi manajemen publik dapat dikatakan memiliki pengaruh atau dampak yang kurang signifikan (Damanhuri, 2017). Hal tersebut juga nampak sebagaimana sistem intelektual politik demokrasi China, teori tata kelola teoritis dan praktis penting untuk membangun kembali serta mencari institusi platform untuk pemerintahan yang baik, sehingga mengubah model pembuatan kebijakan publik dan menyingkirkan praktik administrasi publik dalam proses pengembangan berorientasi pasar yang tidak efisien, atau bahkan gagal dalam banyak hal (Yu Keping, 2018). Hal tersebut tentunya 
tidak harus meningkatkan kompleksitas dengan mengganti orang yang bekerja di layanan publik, tetapi melatih pejabat yang ada, menyosialisasikannya dalam situasi baru dan membuat aparatur pemerintah secara keseluruhan lebih inklusif (de Vries, 2013).

\section{PEMBAHASAN}

\section{Profil Industri Kreatif di Kota Yogyakarta}

Kota Yogyakarta merupakan kota yang identik dengan industri kreatif. Hal ini dikarenakan Kota Yogyakarta memiliki banyak destinasi sebagai tempat wisata. Tercatat bahwa beberapa destinasi pariwisata di Kota Yogyakarta telah dikunjungi $\quad 300.000 \quad$ wisatawan mancanegara, dimana secara keseluruhan kunjungan wisatawan selama tahun 2017 mencapai 3 juta wisatawan (Gil, 2017). Tingginya jumlah kunjungan wisatawan di Kota Yogyakarta, maka besar kemungkinan munculnya pertumbuhan dan juga perkembangan industri kreatif yang berada didalamnya. Dari 10 Kota Kreatif di Indonesia yang diidentifikasi Badan Ekonomi Kreatif, Kota Yogyakarta menduduki peringkat ke-3 (Damayantho, 2017). Dalam hal ini, pemerintah daerah Kota Yogyakarta memprioritaskan beberapa sektor industri kreatif yang menjadi andalan Kota Yogyakarta. Sektor industri tersebut adalah fashion, kerajinan, film animasi video dan seni pertunjukan. Keberadaan pertumbuhan dan perkembangan industri kreatif di Kota Yogyakarta, tidak hanya dikarenakan sebagai destinasi para wisatawan, melainkan juga didukung oleh kemampuan budayawan Kota Yogyakarta. Hal ini kemudian melahirkan beragamnya kekuatan industri kerajinan dan juga seni pertunjukan, dimana sebagai nilai keunggulan utama Kota Yogyakarta. Kreativitas yang dimiliki budayawan di Kota Yogyakarta ini memiliki ke-khas-an tersendiri. Ke-khas-an tersebut sudah mengakar dalam masyarakat Kota Yogyakarta terkait dengan kesederhanaan dalam ide maupun dalam menyelesaikan permasalahan.

Munculnya kreativitas para budayawan di Kota Yogyakarta kemudian berdampak pada nilai ekonomi dari pertumbuhan dan juga perkembangan industri kreatif tersebut. Hal ini tentu bersinergi dengan Kota Yogyakarta sebagai 
destinasi wisata. Hal tersebut yang kemudian disebut dengan industri kreatif.

Dalam hal ini, industri kreatif sebagian besar dijalankan oleh para UMKM. Nilai ekonomi dari produk maupun jasa yang ada dan juga Kota Yogyakarta sebagai destinasi wisata dapat menjadi pemasukan bagi keuangan daerah. Artinya, UMKM harus menjadi fokus perhatian Pemerintah Kota Yogyakarta terkait dengan pengembangannya.

Selaras dengan perkembangan teknologi informasi dan komunikasi serta pergeseran paradigma tata kelola pemerintahan, dimana paradigma yang sedang didorong adalah e-governance. Pemerintah beranggapan bahwa UMKM adalah identitas, kearifan lokal, dan bentuk kemandirian yang dapat menjadi ujung tombak pemerintah dalam memenangkan pasar. Oleh karena itu, perlu adanya sinergi antar aktor-aktor yang terlibat di dalam pengembangan UMKM di era digital. Hal ini harus menjadi fokus dikarenakan persaingan UMKM ini tidak hanya antar UMKM di Kota Yogyakarta, antara UMKM Kota Yogyakarta dengan daerah-daerah lain, maupun antar UMKM Kota Yogyakarta dengan UMKM dari luar negeri. Hal tersebut dikarenakan tidak adanya batas ruang dan waktu dalam persaingan bisnis dari para UMKM dengan adanya ecommerce di era digital.

Menalar Aktor-Aktor Yang Terlibat Dalam Pemberdayaan UMKM Berbasis $E$-commerce

a) Profil Dinas Koperasi Usaha Mikro Kecil Menengah

Dengan mengusung tagline Profesional, Ramah, dan Efektif, Dinas Koperasi, UMKM, Tenaga Kerja dan Transmigrasi mempunyai tugas melaksanakan urusan pemerintah daerah di bidang koperasi, usaha mikro, kecil, dan menengah. Untuk melaksanakan tugas tersebut dinas mempunyai fungsi :

1. penyusunan program dan pengendalian di bidang koperasi, usaha mikro kecil dan menengah

2. perumusan kebijakan teknis bidang koperasi, usaha mikro kecil dan menengah

3. pelaksanaan kerjasama koperasi, usaha mikro kecil dan menengah

4. pemberian fasilitasi, pembinaan, perlindungan, pemasaran dan pengembangan koperasi, usaha mikro kecil dan menengah 
5. pelaksanaan pelayanan umum bidang koperasi, usaha mikro kecil dan menengah

6. pemberian fasilitasi bidang koperasi, usaha mikro kecil dan menengah

7. pemberdayaan sumber daya dan mitra kerja bidang koperasi, usaha mikro kecil dan menengah

8. pelaksanaan kegiatan ketatausahaan

\section{b) Profil Dewan Kerajinan Nasional tingkat Daerah (Dekranasda)}

Terbangunnya kesadaran akan kelangsungan hidup dari kerajinan yang menopang kehidupan masyarakat yang dihadapkan pada kemajuan teknologi industri di satu sisi dan pelestarian nilai budaya bangsa yang harus tercermin dalam produk kerajinan di sisi yang lain, maka dipandang perlu adanya wadah partisipasi masyarakat bertaraf nasional maupun daerah yang berfungsi membantu dan sebagai mitra pemerintah dalam membina dan mengembangkan kerajinan. Oleh karena itu, hal tersebut yang menjadi latarbelakang berdirinya Dewan Kerajinan Nasional (Dekranas) yang dibentuk berdasarkan Surat Keputusan Bersama 2 Menteri, yaitu Menteri Perindustrian dan Menteri Pendidikan dan Kebudayaan, Nomor: 85/M/SK/3/1980 dan Nomor: 072b/P/1980, tanggal 3 Maret 1980 di Jakarta. Untuk mendukung kelancaran kegiatannya di tingkat daerah, dengan dipayungi Surat Menteri Dalam Negeri Nomor: 537/5038/Sospol, tanggal 15 Desember 1981, maka dibentuklah organisasi Dekranas tingkat daerah (Dekranasda). Lebih lanjut, kepengurusan Dekranasda dikukuhkan oleh ketua umum Dekranas atas usulan daerah.

Pada perkembangannya sebagai antisipasi adanya pasar global maupun pasar ASEAN yang telah diberlakukan sejak 1 Januari 2016, maka Dekranasda harus mampu berkordinasi, bersinergi dan berintegrasi dengan pemerintah maupun dengan mitra, agar dapat mengikuti perkembangan pasar global tersebut, dengan cita-cita dari Yogyakarta untuk Indonesia. Maju ataupun mundurnya perkembangan kerajinan sebagai warisan budaya tergantung dari beberapa faktor, dimana faktor-faktor yang berpengaruh adalah transformasi masyarakat yang disebabkan oleh teknologi yang semakin modern, minat dan penghargaan masyarakat terhadap barang kerajinan, serta tetap terjaga kualitas para perajin itu sendiri, baik dalam menjaga mutu dan kreativitas maupun dalam penyediaan produk kerajinan secara berkelanjutan. Dekranas sendiri mempunyai tujuan, yaitu:

1. menggali, mengembangkan dan melestarikan warisan budaya bangsa serta membina penemuan dan penggunaan teknologi baru untuk meningkatkan kualitas dalam 
rangka memperkokoh jati diri budaya bangsa

2. menanamkan kesadaran masyarakat terhadap pentingnya seni kerajinan bagi kehidupan sehari-hari warga negara Indonesia yang bisa meningkatkan martabat manusia.

3. memperhatikan dan memperjuangkan kepentingan perajin dan peminat dengan mendorong semangat

kewiraswastaan mereka

4. membantu pemerintah merumuskan kebijaksanaan di bidang industri kerajinan dan program peningkatan kualitas sumber daya manusia

5. memperluas pangsa pasar hasil kerajinan

c) Profil UMKM Home Business Camp (HBC)

Home Business Camp (HBC) merupakan model mencetak wirausaha muda baru di Kota Yogyakarta dengan berbasiskan pada hobby dan pendampingan yang tepat sesuai keinginan dan kebutuhan. Visi dari UMKM HBC adalah kewirausahaan menjadi tiang ketahanan ekonomi dan sosial. Oleh karena itu, HBC berkeinginan untuk menumbuhkan wirausaha muda yang handal dan berkualitas, karena wirausaha muda merupakan sumber daya yang potensial, kreatif, dan inovatif serta mempunyai keinginan yang kuat untuk maju dan berkembang. Hal ini yang kemudian menjadi dasar bagi HBC untuk semangat produktif, inovatif, kreatif, memanfaatkan keterbatasan, mencari relasi, memanfaatkan relasi dengan optimal, dan juga mengatur diri serta lingkungan sehingga mampu menciptakan hasil yang bermanfaat dan bermartabat. Beberapa inovasi dalam HBC adalah mendidik wirausaha muda yang sudah merintis usaha berbasis hobby dengan sistem camp, kegiatan pelatihan pendampingan oleh konsultan bisnis pelatihan lanjutan hingga peningkatan wawasan, dan juga dipertemukan dengan berbagai pihak untuk gelar produk serta memfasilitasi produk yang dihasilkan. Mekanisme dalam HBC tersebut dengan cara pengadaan pelatihan selama 5 hari dan pendampingan usaha 2 tahun. Hal ini memungkinkan arah pengembangan anggota HBC dapat mandiri, melakukan pemberdayaan lingkungan, mentor.

Adapun pelatihan dalam HBC, dimana pelaksanaannya selama 5 hari, berupa kebijakan pengembangan usaha Usaha Mikro Kecil, konsep dan filosofi HBC, motivasi berwirausaha, berpikir perubahan, branding produk, bisnis online, membangun jejaring, manajemen keuangan, manajemen arsip dan pembukuan, manajemen pemasaran, perencanaan bisnis, packaging, etika bisnis, customer service, marketing produk di media massa, strategi pemilihan usaha, pajak, serta soft bond. Pelatihan ini menggandeng narasumber dari Dinas 
Koperasi, UMKM, Tenaga Kerja dan Transmigrasi Kota Yogyakarta, praktisi, akademisi perguruan tinggi, motivator, maupun stakeholder terkait.

Nantinya, anggota HBC memahami dan melakukan terkait mempunyai produk yang berkarakter, paham strategi bisnis, paham etika bisnis, paham teknik menjemput sukses, mampu mencari mitra, hingga perijinan lengkap, taat pajak, dan juga tidak mengganggu lingkungan. Dengan demikian, diharapkan anggota HBC mendapatkan outcome berupa menjadi trainer dan konsultan bisnis bagi sesama, menjadi pelaku usaha muda mandiri, memiliki wadah berupa koperasi ataupun badan sosial sehingga dapat mengentaskan kemiskinan, bergabung dengan forkom, menjadi anggota asosiasi usaha sejenis, maupun menjadi penggerak wirausaha muda. Beberapa produk dari HBC antara lain Batikianart, Wellflair, Creative Batik, Mie Ayam Pelangi, Sunday surprise, Girls Collection Indonesia, Dluwang Art, Inferno Combo, Smart Batik, Jojo, Tees Anak, Cireng Jupe.

\section{Sebuah usaha : Kebijakan Pemberdayaan UMKM Melalui E-commerce}

Dalam data UMKM Kota Yogyakarta tahun 2013, ada sejumlah 23.604 unit usaha UMKM. Hal ini kemudian membuat UMKM dapat membuka lapangan pekerjaan bagi 34,915 pekerja dengan nilai investasi 132.161.058.328 rupiah. Pada program pemberdayaan UMKM melalui e-commerce,
Dinas Koperasi, UMKM, Tenaga Kerja dan Transmigrasi melakukan kegiatan pelaksanaan dan pendampingan. Pada awalnya, Dinas Koperasi Usaha Mikro Kecil Menengah Kota Yogyakarta membentuk forum komunitas (forkom) bagi pelaku UMKM. Tentunya, dibentuknya forkom ini sebelum adanya kebijakan terkait $\boldsymbol{e}$ commerce. Terkait dengan e-commerce, kebijakan bagi UMKM mengenai $e$ commerce mulai muncul pada tahun 2011/2012. Pada saat adanya kebijakan terkait e-commerce, kebijakan tersebut mendapatkan respon positif. Pertama kali program pelatihan, pelaksanaan dan pendampingan UMKM mengenai $e$ commerce dilaksanakan di XT Square Kota Yogyakarta. Kegiatan ini diikuti oleh Forkom UMKM Kecamatan Kota Yogyakarta. Pada perjalanannya, pelaksanaan program ini mengalami kendala yakni kerepotan dalam maintance sehingga kurang maksimal dalam memanfaatkan e-commerce. Artinya, secara garis besar hambatan utama adalah terkait kurangnya sumber daya manusia. Oleh karenanya, Dinas Koperasi Usaha Mikro Kecil Menengah Kota Yogyakarta bekerjasama dengan Bank Negara Indonesia (BNI). Hal tersebut mendapatkan respon yang baik dari UMKM, hal ini dirasa sangat membantu karena dapat mengetahui ilmu dan detail juga yang dibutuhkan oleh para UMKM.

Selain Forkom UMKM Kecamatan, Dinas Koperasi Usaha Mikro Kecil Menengah Kota Yogyakarta juga memunculkan Home Business Camp (HBC). Home Business Camp 
(HBC) merupakan wadah bagi UMKM yang mayoritas adalah anak muda. Seperti halnya Forkom UMKM Kecamatan, Home Business Camp (HBC) juga mendapatkan bantuan dari Dinas Koperasi Usaha Mikro Kecil Menengah Kota Yogyakarta berupa penyediaan stand di Malioboro Mall dan Galeri Mall di Kota Yogyakarta. Hal ini dimaksudkan agar UMKM Home Business Camp (HBC) mendapatkan tempat untuk pengenalan pemasaran produk mereka. Pada perkembangannya, Home Business Camp (HBC) berkembang dengan baik.

Dengan demikian, Dinas Koperasi Usaha Mikro Kecil Menengah Kota Yogyakarta telah memberikan beberapa program pemberdayaan bagi para UMKM di Kota Yogyakarta. Maksud di dalam bantuan tersebut agar para UMKM dapat bersiap, berkembang dan juga bersaing di tengah pemberlakuan pasar global maupun pasar ASEAN pada tahun 2016. Oleh karena, dalam pemberlakuan pasar global dan pasar ASEAN, maupun dengan adanya metode $e$ commerce, perlu adanya keberpihakan terhadap keberadaan UMKM. Hal ini dikarenakan pasar global, pasar ASEAN, ecommerce bukan hanya dapat membawa persaingan sehingga dapat membawa kearah ketidakberdayaan UMKM Kota Yogyakarta itu sendiri, tetapi juga dapat membawa manfaat bagi UMKM Kota Yogyakarta untuk lebih mengembangkan pasar maupun nilai ekonomi dari keberadaan usaha mereka. Semua itu tergantung kepada kemampuan para UMKM Kota Yogyakarta.
Partisipasi anggota UMKM di Kota Yogyakarta menunjukkan kondisi yang baik, terlihat dari banyaknya peserta yang interest untuk mengikuti program yang diadakan oleh Dinas Koperasi, UMKM, Tenaga Kerja, dan Transmigrasi. Selain itu, secara teoritik, partisipasi yang terdapat pada pengembangan UMKM di Kota Yogyakarta termasuk kedalam kategori partisipasi sebagai cara. Dalam hal ini, kateogori partisipasi yang dimaksud adalah partisipasi yang berimplikasi pada penggunaan partisipasi untuk mencapai tujuan atau sasaran yang telah ditetapkan. Hal ini merupakan suatu upaya pemanfaatan sumber daya yang ada untuk mencapai tujuan program. Penekanan terletak pada mencapai tujuan dan tidak perlu pada aktivitas partisipasi itu sendiri. Artinya, seringkali partisipasi tersebut umumnya jangka pendek.

Lebih lanjut, dalam pemberdayaan yang dilakukan oleh Dinas Koperasi Usaha Mikro Kecil Menengah Kota Yogyakarta masih kurang optimal dalam hal yang terkait pengembangan e-commerce pada UMKM karena hanya sebatas pengetahuan kontekstual saja, namun secara aplikatif dalam pengembangan website, SEO, dan marketplace produk sesuai standar itu belum ada. Sehingga dibutuhkan kontrol intensif terhadap masing-masing binaan UMKM agar program ini dapat berjalan secara berkelanjutan. Meskipun demikian, paradigma pemberdayaan dalam pembangunan yang dilakukan oleh Dinas 
Koperasi Usaha Mikro Kecil Menengah Kota Yogyakarta telah menggunakan paradigma baru. Artinya, paradigma ini melihat pertumbuhan yang berkualitas dan berkelanjutan sehingga terdapat proses keterlibatan warga yang marginal dalam pengambilan keputusan. Kegiatan tersebut menonjolkan nilai-nilai kebebasan dan otonomi. Dalam ha ini, pemerintah daerah melalui Dinas Koperasi Usaha Mikro Kecil Menengah Kota Yogyakarta berada pada membuat lingkungan yang memungkinkan untuk berkembangnya UMKM. Selain nilainilai kebebasan dan otonomi, terdapat juga penghargaan terhadap kearifan dan teknologi lokal maupun pengembangan teknologi secara partisipatoris.

Diharapkan terjadinya penguatan institusi untuk melindungi aset komunitas miskin. Artinya, pembangunan adalah proses multidimensi dan sering tidak nyata yang dirumuskan oleh rakyat, dimana bersifat menyeluruh dan organisasi belajar nonhirarkis. Dengan demikian, peran Dinas Koperasi Usaha Mikro Kecil Menengah Kota Yogyakarta adalah menciptakan kerangka legal yang kondusif, membagi kekuasaan, mendorong tumbuhnya institusi-institusi masyarakat, seperti adanya berbagai macam komunitas bisnis.

Munculnya Home Business Camp (HBC) : Awal Perubahan dan Perseteruan

Pada awalnya, muncul komunitaskomunitas bisnis yang tersebar dan atas inisiatif sendiri dari masyarakat di Kota
Yogyakarta. Home Business Camp sebagai salah satu UMKM di Kota Yogyakarta yang dirintis sejak 2013. Melalui bantuan dari Dinas Koperasi Usaha Mikro Kecil Menengah Kota Yogyakarta, Home Business Camp berkembang menjadi salah satu komunitas bisnis terkenal di Kota Yogyakarta. Perkembangan Home Business Camp yang semakin pesat pada akhirnya menjadi daya tarik yang banyak bagi anak-anak muda di Kota Yogyakarta. Hal ini terkait dengan peningkatan jumlah keanggotaan dan juga keberhasilan dari anggotanya dalam memenangi beberapa kompetisi dan pameran sejak berdirinya Home Business Camp.

Para peserta Home Business Camp ini mayoritas para pemuda yang telah merintis usaha selama 2 tahun, dan para peserta tersebut dikompetisikan untuk mengetahui kemampuan dari masing-masing para anggota Home Business Camp. Atas inisiatif tersebut, Dinas Koperasi Usaha Mikro Kecil Menengah Kota Yogyakarta mengadakan pembinaan dan pelatihan terkait dengan pengelolaan potensi-potensi jenis usaha alternatif dan kreatif di Kota Yogyakarta. Pelatihan dan pembimbingan tersebut dilakukan selama 5 hari dan kemudian mendapatkan kegiatan magang selama 7 hari. Dalam mengikuti pelatihan dan magang tersebut, para anggota Home Business Camp harus menjalankannya sendiri. Home Business Camp menjadi salah satu komunitas yang kemudian dikembangkan sebagai komunitas bisnis yang 
menggunakan media online untuk berbisnis. Oleh karenanya, Home Business Camp diharapkan dapat menjadi pioneer dalam melakukan penjualan melalui e-commerce. Dari pembinaan dan pelatihan Dinas Koperasi Usaha Mikro Kecil Menengah Kota Yogyakarta, lahir angkatan-angkatan yang merupakan hasil kompetisi di tiap tahun dari Home Business Camp tersebut. Nantinya, pemenang dari angkatan-angkatan tersebut yang mendapatkan fasilitas Dinas Koperasi Usaha Mikro Kecil Menengah Kota Yogyakarta. Akibat perkembangan yang pesat, komunitas Home Business Camp mendapatkan perhatian sebagai komunitas bisnis online melalui e-commerce di Kota Yogyakarta.

Keberhasilan Home Business Camp dipandang sebagai perseteruan terutama terakit dengan fasilitas yang didapatkan dari Dinas Koperasi Usaha Mikro Kecil Menengah Kota Yogyakarta. Tercatat, Dinas Koperasi Usaha Mikro Kecil Menengah Kota Yogyakarta memberikan fasilitas bagi pemenang kompetisi Home Business Camp berupa stand tempat berjualan di Malioboro Mall dan Galeria Mall. Meskipun demikian, seiring dengan perkembangan yang dialami oleh Home Business Camp, konflik pun terjadi akibat adanya fasilitas yang diberikan dan terdapat pihak yang ingin mendapatkan seperti yang didapatkan oleh Home Business Camp. Antara lain adalah resistensi antara Forkom UMKM Kecamatan dan Home Business Camp, dimana seperti halnya permasalahan antara pendahulu dengan pemula. Perasaan selanjutnya pun terkait dengan kecemburuan dari masing-masing pihak terkait dengan kebijakan dan program yang dilakukan oleh Dinas Koperasi Usaha Mikro Kecil Menengah Kota Yogyakarta, baik yang diberikan kepada Forkom UMKM Kecamatan maupun Home Business Camp. $\mathrm{Hal}$ ini tentunya menjadi agenda penting yang harus dipikirkan solusinya melalui kebijakan maupun program selajutnya sehingga hal tersebut tidak muncul kembali.

\section{Rekonsiliasi : Terjaganya Konsensus Berdasarkan Kultural}

Dalam suatu kebijakan, maka akan berbicara tentang siapa mendapat apa, kapan, dan seberapa banyak. Oleh karena, dalam kebijakan pasti ada pihak yang diuntungkan maupun dirugikan. Seringkali, hal ini terkait dengan pembagian alokasi dan distribusi yang terdapat dalam kebijakan tersebut. Hal tersebut yang kemudian dapat menimbulkan konflik. Oleh karena itu, perlu adanya peran pemerintah dalam mengelola konflik. Tentunya hal ini menjadi rumit ketika struktur ekonomi yang berlangsung adalah ekonomi pasar. Namun, ironisnya ekonomi pasar juga sangat bergantung pada institusi-institusi pasar yang efektif dan kapabilitas negara untuk menciptakan dan menegakkan aturan main serta sejumlah insentif yang mendorong pertumbuhan.

Dalam ide ekonomi pasar, institusi pemerintah telah ditransformasikan dan sebagian digeser ke dalam arena-arena instusional diluar negara dan bekerja sesuai logika pasar. Di sisi lain, ada logika politik 
pemerintah yang khawatir terhadap kompetisi dan ketidakpastian yang dibawa oleh pasar. Disinilah terletak arti penting atau posisi strategis yang harus dimainkan oleh pemerintah. Pemerintah perlu mengembangkan kapasitasnya untuk memonitor, memahami cara kerja, dan kalau perlu merekasaya bekerjanya pasar agar dampak negatif dari ekonomi pasar dapat diminimalisir. Prasyarat untuk itu adalah adanya kapasitas berfikir dan berfikir strategis, sedemikian sehingga tidak hanya, apalagi menjadi bulan-bulanan dari skema yang disebut market-based governance. Selain menciptakan dan menegakkan aturan main serta sejumlah insentif, logika ini kemudian melahirkan dorongan bagi pemerintah untuk mengambil inisiatif yang akan memperkuat sistem perlindungan sosial. Artinya, kemampuan kapasitas birokrasi dan sistem menentukan keberhasilan dalam keteraturan keberlangsungan pasar.

Tata pemerintahan yang demokratis mengkombinasikan ciri-ciri dari rezim politik yang memberikan warga negara hak untuk mengatur diri sendiri (demokrasi) dengan struktur dan mekanisme yang dipakai untuk mengelola persoalan publik sesuai dengan aturan dan prosedur yang disepakati. Artinya, masyarakat sipil memiliki peran penting dalam mengembangkan dan mewujudkan pelembagaan democratic governance. Pelembagaan antara pemerintah, pasar, dan juga masyarakat. Hal tersebut bagaimana peran pemerintah dalam membangun dan menjaga kondisi maupun situasi yang ada, pasar dapat terjaga dengan adanya pertumbuhan dan berjalannya pasar maupun nilai ekonomi yang ada didalamnya tersebut, dan juga masyarakat yang dapat mengisi dan mengatur serta mengelola pasar maupun eksternalitas pasar tersebut dengan kesadaran sendiri sesuai keinginan mereka berdasar pada aturan dan prosedur yang disepakati.

Selain penekanan dari kebijakan maupun program dari Dinas Koperasi Usaha Mikro Kecil Menengah Kota Yogyakarta, sentimen yang muncul dapat teratasi karena adanya kultur masyarakat Kota Yogyakarta yang menjunjung pakem ewuh-pakewuh. Hal ini yang kemudian dirasakan sangat berpengaruh dalam menekan masing-masing komunitas bisnis untuk tidak memaksakan kepentingan dan juga tetap patuh kepada kebijakan maupun program yang telah ada. Hal ini tentunya selaras dengan konsep democratic governance. Konsep democratic governance menunjukkan bahwa demokrasi dan good governance bersifat saling melengkapi dan bergantung. Keduanya dapat dimasukkan kedalam satu konsep tata pemerintahan yang demokratis. Keduanya juga melihat problem pembangunan yang sama dari dua perspektif yang berbeda, yang pertama dari perspektif politik dan yang kedua dari perspektif ekonomi. Oleh karena itu, dapat dikatakan bahwa istilah tata pemerintahan yang demokratis mencerminkan konvergensi antara persepktif politik dan ekonomi dan antara reformasi politik dan ekonomi.

Terdapatnya kultur masyarakat Kota Yogyakarta yang menjunjung pakem ewuhpakewuh adalah perwujudan dari sosiokultur kehidupan masyarakat Jawa. Ewuhpekewuh merupakan penunjukkan sikap maupun perasaan ketidakenakan atau keengganan seseorang atau sekelompok orang terhadap pihak lain maupun kondisi yang ada. Terdapatnya sikap maupun perasaan tersebut, maka akan terbentuk 
kondisi saling menjaga antar pihak atas perilaku dan ucapannya yang dirasa dapat menyinggung. Hal tersebut tentunya secara tidak langsung terpengaruh dan dibentuk dari adanya budaya patrimonial, dimana adanya struktur tua-muda, atasan-bawahan, senior-yunior, ningrat-jelata. Selain itu, sikap ini dapat muncul saat individu sudah mengenal maupun menerima suatu kebaikan maka individu atau kelompok tersebut akan sulit untuk menolak, bahkan menentang pada khususnya.

Dalam rekonsiliasi terkait

kecemburuan dari masing-masing kedua belah pihak, pihak Home Business Camp (HBC) lebih mengedepankan ewuh-pekewuh. Sikap tersebut juga terlihat pada saat adanya materi pelatihan yang diberikan oleh Dinas Koperasi Usaha Mikro Kecil Menengah Kota Yogyakarta. Home Business Camp (HBC) merasakan bahwa materi yang diberikan kurang sesuai dengan kebutuhan dari masing-masing anggota komunitas bisnis tersebut. Perubahan-perubahan materi terkait dengan pelatihan pengembangan UMKM berbasis e-commerce tersebut dibutuhkan untuk penyesuaian kemampuan yang sangat dibutuhkan dan sesuai dengan kondisi masing-masing anggota komunitas bisnis tersebut. Hal ini seharusnya dilakukan dikarenaka kondisi ekonomi saat ini bersifat dinamis dan reaktif. Namun, anggota komunitas bisnis Home Business Camp (HBC) tidak menyampaikan keinginan mereka dikarenakan adanya perasaan ewuhpekewuh. Begitu juga, terkait dengan perasaan kecemburuan yang muncul. Mereka lebih memilih untuk memendam hal tersebut. Artinya, situasi dan kondisi tetap terjaga berdasarkan pada sosio-kultur dalam menjaga konsensus yang ada.

Dengan demikian, perasaan ewuhpekewuh memiliki kelebihan dalam meredam konflik dan menjaga konsensus yang telah disepakati. Namun, disisi lain perasaan ini kemudian tidak melahirkan sikap partisipatif dalam memanfaatkan ruang publik untuk memperbaiki pengembangan UMKM. Pemanfaatan ruang publik lebih digunakan oleh pemerintah untuk melaksanakan implementasi kebijakan maupun program. Artinya, partisipasi yang terjadi dalam pengembangan UMKM berbasis e-commerce didominasi oleh Dinas Koperasi Usaha Mikro Kecil Menengah Kota Yogyakarta melalui pendamping UMKM.

\section{Kesimpulan}

Partisipasi anggota UMKM di Kota Yogyakarta menunjukkan kondisi yang baik, terlihat dari banyaknya peserta yang interest untuk mengikuti program yang diadakan oleh Dinas Koperasi, UMKM, Tenaga Kerja, dan Transmigrasi. Selain itu, secara teoritik, partisipasi yang terdapat pada pengembangan UMKM yang dilakukan di Kota Yogyakarta termasuk kedalam kategori partisipasi sebagai cara. Dalam hal ini, kateogori partisipasi yang dimaksud adalah partisipasi yang berimplikasi pada penggunaan partisipasi untuk mencapai tujuan atau sasaran yang telah ditetapkan. 
Hal ini merupakan suatu upaya pemanfaatan sumber daya yang ada untuk mencapai tujuan program. Penekanan terletak pada mencapai tujuan dan tidak perlu pada aktivitas partisipasi itu sendiri.

Meskipun demikian, pemberdayaan yang dilakukan oleh Dinas Koperasi Usaha Mikro Kecil Menengah Kota Yogyakarta masih kurang optimal dalam hal yang terkait dengan pengembangan e-commerce pada UMKM karena hanya sebatas pengetahuan kontekstual saja, dimana secara aplikatif dalam pengembangan website, SEO, dan marketplace produk tersebut belum ada yang sesuai standar. Oleh karena itu, dibutuhkan kontrol intensif terhadap masing-masing binaan UMKM agar program ini dapat berjalan secara berkelanjutan. Selanjutnya, paradigma pemberdayaan dalam pembangunan yang dilakukan oleh Dinas Koperasi Usaha Mikro Kecil Menengah Kota Yogyakarta telah menggunakan paradigma baru. Artinya, paradigma ini melihat pertumbuhan yang berkualitas dan berkelanjutan sehingga terdapat proses keterlibatan warga yang marginal dalam pengambilan keputusan. Kegiatan tersebut menonjolkan nilai-nilai kebebasan dan otonomi. Dalam hal ini, pemerintah daerah melalui Dinas Koperasi Usaha Mikro Kecil Menengah Kota Yogyakarta berada pada membuat lingkungan yang memungkinkan untuk berkembangnya UMKM. Selain nilainilai kebebasan dan otonomi, terdapat juga penghargaan terhadap kearifan dan teknologi lokal maupun pengembangan teknologi secara partisipatoris. Diharapkan terjadinya penguatan institusi untuk melindungi aset komunitas miskin. Artinya, pembangunan adalah proses multidimensi dan sering tidak nyata yang dirumuskan oleh rakyat, dimana bersifat menyeluruh dan organisasi belajar non-hirarkis. Dengan demikian, peran Dinas Koperasi Usaha Mikro Kecil Menengah Kota Yogyakarta adalah menciptakan kerangka legal yang kondusif, membagi kekuasaan, mendorong tumbuhnya institusi-institusi masyarakat, seperti adanya berbagai macam komunitas bisnis.

Lebih lanjut, perkembangan komunitas bisnis di Kota Yogyakarta pada akhirnya membuat masing-masing pihak untuk berpikir bagaimana perselisihan ini dapat diatasi. Bagi Dinas Koperasi Usaha Mikro Kecil Menengah Kota Yogyakarta, para komunitas bisnis ini dapat berkerjasama dan tidak menimbulkan permasalah diantara mereka. Asumsi yang sama tersebut kemudian juga dirasakan dan dipikirkan oleh para masing-masing pihak. Hal tersebut dikarenakan terdapat kultur masyarakat Kota Yogyakarta yang menjunjung pakem ewuhpakewuh Terdapatnya sikap maupun perasaan tersebut, kemudian yang membentuk kondisi saling menjaga antar pihak atas perilaku dan ucapannya yang dirasa dapat menyinggung. Dalam pikiran mereka bahwa mereka juga adalah komunitas bisnis yang seharusnya saling membantu, menghargai suatu kebijakan maupun program yang diberikan oleh Dinas Koperasi Usaha Mikro Kecil Menengah Kota 
Yogyakarta kepada masing-masing pihak meskipun berbeda-beda, serta menjaga kondisi dan situasi ekonomi maupun iklim bisnis Kota Yogyakarta.

Dengan demikian, Dinas Koperasi Usaha Mikro Kecil Menengah Kota Yogyakarta telah melakukan berbagai upaya pemberdayaan berupa pendampingan dan pelatihan kepada masing-masing komunitas bisnis tersebut. Hal ini tetap dilakukan karena dengan adanya pemberdayaan maka dapat meningkatkan pemberdayaan komunitas tersebut. Dinas Koperasi Usaha Mikro Kecil Menengah Kota Yogyakarta berharap dengan tetap adanya pemberdayaan tersebut maka komunitas bisnis tetap fokus pada masing-masing keunggulan dan lingkup pangsa pasar yang dimiliki. Hal ini kemudian diharapkan juga dapat mengurangi sentimen antar komunitas bisnis tersebut.

\section{DAFTAR PUSTAKA}

Abiwu, Felix Kumah. 2017. Democratic Institutions, Natural Resource Governance, and Ghana's Oil Wealth. Dalam

http://www.mdpi.com/2076-

$0760 / 6 / 1 / 21$, yang diakses pada 20 April 2018.

Damanhuri, dan Roni Jawandi. 2017. Reaktualisasi Reformasi Birokrasi Menuju Good Governance dalam Prosiding Seminar Nasional Pendidikan. Serang: FKIP UNTIRTA.

Damayantho, Tri. 2017. 10 Kota Kreatif di Indonesia (2). dalam http://indonesiakreatif.bekraf.go.id/ik news/10-kota-kreatif-di-indonesia-2/, yang diakses pada 20 Maret 2018.

de Vries, Michiel. 2013. The Challenge of Good Governance. The Innovation Journal: The Public Sector Innovation Journal, 18(1). dalam https://www.innovation.cc/scholarlystyle/de_vries18vila2.pdf, yang diakses pada 20 April 2018.

Diandra. 2016. Kominfo Dorong UMKM Manfaatkan e-Commerce. dalam https://kominfo.go.id/content/detail/ 8548/kominfo-dorong-umkmmanfaatkan-ecommerce/0/sorotan_media, yang diakses pada 26 April 2017.

Dulman, Juraoda Yunaini. 2011. Tesis. Analisis Kebijakan Pemerintah Dalam Pembinaan Usaha Kecil Dan Menengah Untuk Menghadapi ASEAN - China Free Trade Agreement : Studi Kasus Pada Kawasan PIK Pulogadung. Depok : FISIP UI

Gil, 2017. Kota Yogyakarta Dibebankan Menggaet 800.000 Wisatawan Mancanegara. dalam http://jogja.tribunnews.com/2017/12/1 8/kota-yogyakarta-dibebankanmenggaet-800000-wisatawanmancanegara, yang diakses pada 20 Maret 2018.

Humas Kemenko Perekonomian. 2016. Paket Kebijakan Ekonomi XIV: Peta Jalan E-Commerce!. dalam 
https://www.kominfo.go.id/content/d

etail/8356/siaran-pers-tentang-

paket-kebijakan-ekonomi-xiv-peta-

jalan-e-commerce/0/siaran_pers,

yang diakses pada 26 April 2017.

Kumorotomo, Wahyudi. 2008. Makalah.

Perubahan Paradigma Peran

Pemerintah Dalam Pemberdayaan

Koperasi dan UMKM. Dalam

http://kumoro.staff.ugm.ac.id/wp-

content/uploads/2008/09/perubahan

-paradigma-peran-pemerintah-dlm-

pemberdayaan-koperasi-umkm.pdf,

yang diakses pada 26 April 2017.

Kurniawan, Ferry Duwi dan Luluk Fauziah.

2014. Pemberdayaan Usaha Mikro

Kecil dan Menengah (UMKM)

dalam Penanggulangan Kemiskinan.

Sidoarjo : JKMP Universitas

Muhammadiyah.

Pasaribu, Agnes Hermin Rahayu. 2015. Tesis.

Evaluasi Implementasi Strategy

Execution dalam Rangka

Pemberdayaan UMKM di Bank

Indonesia. Yogyakarta: UGM.

Praditya, llyas lstianur. 2016. 2 Juta UMKM

Akan Berbasis Online pada 2016.

dalam

https://www.liputan6.com/bisnis/rea

d/2481225/2-juta-umkm-akan-

berbasis-online-pada-2016, yang

diakses pada 26 April 2017.

Siswanto, Heru. 2011. Tesis. Peran Perbankan

Dalam Pemberdayaan UMKM Dan

Pengaruhnya Terhadap Ketahanan

Ekonomi Masyarakat (Studi di Bank
Syariah Mandiri Cab. Kota Depok

Prov. Jawa Barat). Yogyakarta: UGM.

Swasanany, Winantuningtyas Titi. 2013.

Proses Formulasi Kebijakan

Pembentukan Daerah Otonom Baru

Di Indonesia (Perspektif Democratic

Governance). Kajian Vol. 18 No.2 Juni 2013. dalam

http://jurnal.dpr.go.id/index.php/kaji

an/article/view/479, yang diakses pada 20 April 2018.

Umar, Ismail, Ade M. Yuardani dan Hasymi Rinaldi. 2013. Peran Pemerintah Desa dalam Meningkatkan Partisipasi Masyarakat di Desa Rasau Jaya Umum. Pontianak: Jurnal Eksos.

Viska. 2017. UMKM Go Online, Upaya Wujudkan Visi "Digital Energy of Asia”. dalam https://www.kominfo.go.id/content/d etail/9514/umkm-go-online-upayawujudkan-visi-digital-energy-ofasia/0/berita_satker, yang diakses pada 26 April 2017.

Yu Keping. 2018. Governance and Good Governance: A New Framework for Political Analysis. Fudan Journal of the Humanities and Social Sciences, Vol. 11, lssue 1. dalam https://link.springer.com/content/pdf /10.1007\%2Fs40647-017-0197-4.pdf, yang diakses pada 20 April 2018. 